\title{
Punctularia strigosozonata (Punctulariaceae) in Europe
}

\author{
MARGARITA A. BONDARTSEVA, VERA M. LOSITSKAYA and IVAN V. ZMITROVICH
}

\begin{abstract}
BONDARTSEVA, M.A., LOSITSKAYA, V.M. \& ZMITROVICH I.V. 2000: Punctularia strigosozonata (Punctulariaceae) in Europe. - Karstenia 40: 9-10. Helsinki. ISSN 0453-3402.
\end{abstract}

Punctularia strigosozonata (Schwein.) P.H.B. Talbot is reported from nine localities in the European part of Russia, Belarus and Estonia. Spore dimensions of the collections are given.

Key words: Belarus, distributions, Estonia, North Europe, Punctularia, Russia

Margarita A. Bondartseva, Vera M. Lositskaya and Ivan V. Zmitrovich, V.L. Komarov Botanical Institute, 2 Popov Street, St. Petersburg 197376, Russia

\section{Introduction}

Punctularia strigosozonata (Schwein.) P.H.B. Talbot has characteristic, well visible fruit bodies and grows on fallen tree trunks or large branches. In spite of such a marked appearance it is almost unknown in Europe. This beautiful fungus with resupinate or reflexed fruitbody is at first orbicular and then confluent and rather large, with zonate, brown upper surface and lighter margin (yellow-brown when fresh) and even, tuberculate or phlebioid, dark brown hymenial surface. It grows on rotten wood of deciduous trees (Populus, Betula, Alnus, Salix, Acer, Quercus) mainly in the regions with warm temperate, subtropical and tropical climate. Cooke (1956) reported the species from North and South America, China and the former Soviet Union. According to Jülich and Stalpers (1980) the species grows in Europe but they did not give exact data on the distribution. Eriksson et al. (1981) presented a single find from Estonia, and Hjortstam (1984) reported the first collection (Pohjois-Karjala, eastern Finland) from the Nordic countries. We here list the known localities from the European part of Russia, Estonia and Belarus and give data on the spore dimensions on the basis of the present collections.

\section{Material and methods}

The study is based on the microscopical examination of the specimens listed below. The vouchers are preserved in the Mycological herbarium of V.L. Komarov Botanical Institute RAN (LE). Potassium hydroxide (5\%) was the mounting medium used when making measurements. From every collection 20 - 30 spores were measured. The following abbreviations are used: $\mathrm{L}$ - spore length, $\mathrm{L}^{*}$ - the mean spore length with standard deviation, W - spore width, $\mathrm{W}^{*}$ - the mean spore width with standard deviation, $\mathrm{Q}$ - range of the variation in $\mathrm{L} / \mathrm{W}$ ratio, $\mathrm{Q}^{*}$ quotient of the mean spore length and the mean spore width (L/W ratio).

Specimens examined: Russia. Karelian Republic, Kivach State Reserve, Populus tremula, 10.IX.1997 V.M. Lositskaya (LE 206214). Leningrad Region, Nizhnesvirsky Reserve, P. tremula, 27.VIII.1999 M.A. Bondartseva \& I.V. Zmitrovich (LE 208502). Voronezh Region, Tellermanovskoye forest, $P$. tremula, 2.X.1956 E.A. Oganova (LE 166037). Sverdlovsk Region, near village Korzunovka, Sorbus aucuparia 14.IX.1960 N.T. Stepanova-Kartavenko (LE 166036); Tavashuy, P. tremula, 1967 N.T. Stepanova-Kartavenko (LE 166038). Estonia. Väike-Maarja, Kuusikumäe, $P$. tremula, P. canescens (?), 5.X.1956 E. Parmasto (LE 166033, LE 166035). Põlva District, Taevaskoja, Alnus incana, 9.IX.1950 E. Parmasto (LE 166039). Belarus. Brest Region, Dmitrovichi forest, $P$. tremula, 28.VIII.1966 M.A. Bondartseva \& E. Parmasto (LE 166037). 


\section{Results and discussion}

Punctularia strigosozonata has been collected several times in the former Soviet Union but the records have mostly remained unpublished. This is the first report of this species from the Karelian Republic and the Leningrad Region. The collections from Kivach State Reserve and Nizhnesvirsky Reserve are the northernmost ones reported from Europe.
This fungus is adapted advantageously to the old conifer forests with aspen and alder. In Belarus it was collected in pine forest with green mosses, in the Republic of Karelia and Estonia it is known from spruce forest with Vaccinium myrtillus, in Sverdlovsk Region from Picea and Abies stand. Leningrad Region is the only locality where $P$. strigosozonata was found in old aspen forest with herbs and ferns.

Table 1. Spore size of Punctularia strigosozonata specimens collected in northeastern Europe.

\begin{tabular}{lccccccc}
\hline & $\begin{array}{l}\text { Specimens } \\
\text { examined }\end{array}$ & $\mathbf{L}$ & $\mathbf{L}$ & $\mathbf{W}$ & $\mathbf{W}$ & $\mathbf{Q}$ & $\mathbf{Q}^{*}$ \\
\hline $\begin{array}{l}\text { Russia: } \\
\text { Karelian }\end{array}$ & & & & & & & \\
$\begin{array}{l}\text { Republic } \\
\text { Leningrad }\end{array}$ & LE 206214 & $6.5-8.0$ & $7.55 \pm 0.18$ & $2.8-3.5$ & $3.10 \pm 0.13$ & $2.32-2.56$ & $2.44 \pm 0.16$ \\
$\begin{array}{l}\text { Region } \\
\text { Voronezh }\end{array}$ & LE 208502 & $6.5-7.8$ & $7.05 \pm 0.17$ & $3.0-3.5$ & $3.40 \pm 0.14$ & $1.98-2.16$ & $2.07 \pm 0.15$ \\
$\begin{array}{l}\text { Region } \\
\text { Sverdlovsk }\end{array}$ & LE 166041 & $6.5-7.5$ & $6.90 \pm 025$ & $3.2-4.0$ & $3.60 \pm 0.24$ & $1.87-1.97$ & $1.92 \pm 0.25$ \\
Region & LE 166036 & $7.0-9.0$ & $8.10 \pm 0.21$ & $2.8-4.0$ & $3.40 \pm 0.16$ & $2.30-2.50$ & $2.40 \pm 0.18$ \\
& LE 166038 & $7.0-9.5$ & $8.30 \pm 0.20$ & $2.8-4.5$ & $3.50 \pm 0.16$ & $2.14-2.60$ & $2.37 \pm 0.18$ \\
Estonia & LE 166033 & $6.0-7.5$ & $6.70 \pm 0.22$ & $3.0-4.5$ & $3.80 \pm 0.21$ & $1.47-2.16$ & $1.76 \pm 0.22$ \\
& LE 166035 & $7.2-7.5$ & $7.40 \pm 0.18$ & $3.5-4.5$ & $4.00 \pm 0.17$ & $1.60-2.10$ & $1.85 \pm 0.18$ \\
& LE 166039 & $7.5-8.0$ & $7.80 \pm 0.19$ & $3.5-4.5$ & $4.10 \pm 0.17$ & $1.80-2.00$ & $1.90 \pm 0.18$ \\
Belarus & LE 166037 & $7.0-7.8$ & $7.50 \pm 0.18$ & $2.8-4.5$ & $3.60 \pm 0.16$ & $1.70-2.46$ & $2.08 \pm 0.17$ \\
\hline & & & & & & & \\
\hline
\end{tabular}

According to our measurements (Table 1) the spore size of Punctularia strigosozonata is 6$9.5 \times 2.8-4.5 \mu \mathrm{m}(\mathrm{n}=236$ measurement $/ 9$ specimens). The spore dimensions given by Eriksson et al. (1981) and Jülich and Stalpers (1980) fit well with our data. The collections from the boreal zone have longer and narrower spores than the specimens found in more southern localities (the Voronezh Region and Estonia). However, we feel that the difference between the northern and southern specimens is taxonomically insignificant, and the present material belongs to a single species.

Acknowledgements: We are grateful to Drs. H. Kotiranta and P. Renvall for revision of the text. The study was fulfilled with financial support from the Russian Fund of Fundamental Investigations (98-04-48120).

\section{References}

Cooke, W. B. 1956: The genus Phlebia. - Mycologia 48: $386-405$.

Eriksson, J., Hjortstam, K. \& Ryvarden, L. 1981: The Corticiaceae of North Europe. Phlebia to Sarcodontia. - Pp. 1051-1276. Fungiflora, Oslo.

Hjortstam, K. 1984: Corticiaceous fungi of Northern Europe - checklist of the species in the Nordic countries. - Windahlia 14: 1-29.

Jülich, W. \& Stalpers J.A. 1980: The resupinate nonporoid Aphyllophorales of the temperate northern hemisphere. - North-Holland Publ. Comp., Amsterdam. $335 \mathrm{pp}$. 